\title{
AVPR1A wt Allele
}

National Cancer Institute

\section{Source}

National Cancer Institute. AVPR1A wt Allele. NCI Thesaurus. Code C51408.

Human AVPR1A wild-type allele is located within 12q14-q15 and is approximately $6 \mathrm{~kb}$ in length. This allele, which encodes vasopressin $\mathrm{V} 1$ a receptor protein, is involved in the mediation of cell contraction and proliferation, platelet aggregation, release of coagulation factor and glycogenolysis. 